\title{
ЕКСПЕРИМЕНТАЛЬНА МЕДИЦИНА
}

\author{
(c) Polyvyana O.A., Shepitko V.I., Stetsuk Ye.V., Akimov O.Ye., Yakushko O.S., Voloshyna O.V. \\ УДК 616.36-01:612.018.2-02:615.357]-092.9
}

DOI https://doi.org/10.31718/mep.2021.25.5-6.10

\section{MORPHOLOGICAL CHANGES AND OXIDATIVE HOMEOSTASIS IN THE LIVER TISSUES DURING LONG CENTRAL DEPRIVATION OF LUTEINIZING HORMONE SYNTHESIS BY TRIPTORELIN}

\author{
Polyvyana O.A., Shepitko V.I., Stetsuk Ye.V., Akimov O.Ye., Yakushko O.S., Voloshyna O.V.
}

Poltava State Medical University, Poltava

The study is a part of the research project "Experimental morphological study of cryopreserved placenta transplants action diphereline, ethanol and $1 \%$ methacrylic acid on the morphofunctional status in a number of internal organs", state registration No. $0119 \cup 102925$.

Останніми роками увага дослідників прикута до проблеми залежності функціонування різних органів та систем від рівня андрогенів. Питання впливу тривалого пригнічення синтезу тестостерона триптореліном на тканини печінки $\epsilon$ недостатньо вивченим. Метою даного дослідження: з'ясувати мікроскопічну організацію печінки щурів, вироблення оксиду азоту та інтенсивності окисного стресу при експериментальній центральній депривації синтезу лютеїнізуючого гормону шляхом введення дифереліну на 270-360-ту добу експерименту. Експеримент провели на 30 статевозрілих самцях білих щурів лінії Вістар. Щурів розділили на 2 групи: контрольну (10) та дослідну (20). Тваринам дослідної групи підшкірно вводили трипторелін у дозі 0,3 мг діючої речовини/кг маси тіла протягом 360 днів, а контрольній групі - фізіологічний розчин. Встановлено, що в гепатоцитах розвивається оксидативний стрес, який морфологічно підтверджується каріопікнозом ядер, оксифілією цитоплазми з появою в ній значної кількості вакуолей. Судини гемомікроциркуляторного русла реагують стазом. Підвищення продукції супероксидрадикального аніону в печінці щурів може бути пов'язано з відсутністю інгібуючого впливу тестостерону на макрофаги та мітохондрії гепатоцитів, що супроводжується виснаженням антиоксидантних ферментів та розвитком окисного стресу. Інтенсивність біохімічних маркерів окисного стресу на 360-ту добу нижча, ніж на 270-ту, що пов'язано з підвищенням активності антиоксидантних ферментів та зниженням продукції активних форм кисню.

Ключові слова: тканина печінки, триптореліновий ембонат, оксидативний стрес, щури.

In recent years, researchers have focused on the problem of the dependence of the functioning of various organs and systems on the level of androgens. The effect of long inhibition of testosterone synthesis by triptorelin on liver tissue is poorly understood. The aim of this research was to establish the microscopic organization of rat livers, production of nitric oxide and the intensity of oxidative stress in the rat livers during experimental central deprivation of luteinizing hormone synthesis by diphereline injection on the 270-360th day of the experiment. The experiments were carried out on 30 sexually mature male white rats of the Wistar line. Rats were divided into 2 groups: the control group (10) and the experimental group (20). Animals from the experimental group were subcutaneously injected triptorelin at a dose of 0.3 $\mathrm{mg}$ of the active substance/ per $\mathrm{kg}$ of body weight for 360 days, while the control group received an injection of saline. It was found that oxidative stress develops in hepatocytes, which is morphologically confirmed by karyopyknosis of the nuclei, oxyphilia of the cytoplasm with the appearance of a significant number of vacuoles in it. The vessels of the microcirculatory bed react with stasis. An increase in the production of superoxide radical anion in rat liver may be due to the absence of an inhibitory effect of testosterone on macrophages and liver mitochondria, which is accompanied by depletion of antioxidant enzymes and the development of oxidative stress. The intensity of biochemical markers of oxidative stress on the 360th day is lower than on the 270th day, which is due to an increase in the activity of antioxidant enzymes and a decrease in the production of reactive oxygen species.

Key words: liver, triptorelin embonate, oxidative stress, rat

Prostate cancer is one of the most common cancers in men. [2]. Historically, androgen synthesis deprivation was one of the first effective treatments for prostate can-

cer and remains one of the main treatment strategies today. [5]. One of the most effective deprivators of androgen synthesis is the gonadotropin-releasing hormone

${ }^{*}$ To cite this English version: Polyvyana O.A., Shepitko V.I., Stetsuk Ye.V., Akimov O.Ye., Yakushko O.S., Voloshyna O.V. Morphological changes and oxidative homeostasis in the liver tissues during long central deprivation of luteinizing hormone synthesis by triptorelin // The Medical and ecological problems. - 2021. - Vol 25, № 5-6. - P. 39-42. 
agonist triptorelin. $[6,8]$.

There is little data in the scientific literature on the possible toxic direct or indirect effects of long-term use of triptorelin on liver tissue. In our earlier studies, we found that the use of triptorelin for central deprivation of luteinizing hormone synthesis leads to the development of oxidative stress in the liver tissues on day 180 of the experiment [7]. The effect of triptorelin-induced decrease of the luteinizing hormone production on the liver tissue at longer periods of the experiment is not well understood.

The aim of this research was to establish the microscopic organization of rat livers, production of nitric oxide and the intensity of oxidative stress in the rat livers during experimental central deprivation of luteinizing hormone synthesis by diphereline injection on the 270-360th day of the experiment.

\section{Materials and methods}

The experiments were carried out on 30 sexually mature male white rats of the Wistar line. Rats were divided into 2 groups: the control group (10) and the experimental group (20). Animals from the experimental group were subcutaneously injected diphereline (Triptorelin embonate) at a dose of $0.3 \mathrm{mg}$ of the active substance/ per $\mathrm{kg}$ [9] of body weight for 360 days, while the control group received an injection of saline. Animals were kept in standard vivarium conditions of the Poltava State Medical University. Experimental animals were euthanized in strict compliance with the provisions of the "European Convention for the Protection of Vertebrate Animals Used for Experimental and Other Scientific Purposes"; (Strasbourg, 1986), as well as with the "General Ethical Principles of Animal Experiments" adopted by the First National Congress on Bioethics (Kyiv, 2001). Animals from the experimental group were removed from the experiment on the 270th day $(n=10)$ and on the 360th $(n=10)$ day of modeling of central deprivation of testosterone synthesis.

After an overdose of ketamine, the animals were decapitated, the prepared small pieces of the testes were fixed in a $2.5 \%$ glutaraldehyde solution $(\mathrm{pH}=7.2-7.4)$. Postfixation of the material was carried out with $1 \%$ solution of osmium (IV) oxide, followed by dehydration in propylene oxide and a sample was embedded into the epoxy resins mixture. Using standard methods, the material was embedded in paraffin blocks, of which sections $4 \mu \mathrm{m}$ thick were made and stained with hematoxylin and eosin [1]. Histological preparations were examined using Biorex 3 light microscope with digital microfilter with software adapted for these studies (Serial No. 5604).

By using the method of standard areas, the images were photographed with the magnitude of 400 and 1000, using microscope "Micromed" with the TSView software adapted for monitoring.

The volume of the nuclei of hepatocytes was calculated out according to the formula of the ellipse: $V=\pi / 6$ $D \cdot d 2$, where $V$ is the volume of the nucleus, $d$ - the length of the small diameter of the nucleus, D - the length of the large diameter of the nucleus.

All biochemical studies were carried out in $10 \%$ homogenate of testis tissue using Ulab 101 spectrophotometer. The basic production of superoxide anion radical (SAR) was determined by the growth of diformazan concentration, formed in the reaction of SAR with nitro blue tetrazolium. Superoxide dismutase (SOD) activity was determined by inhibition of adrenaline autooxidation, while catalase activity was determined by the amount of hydrogen peroxide, which remained after its catalasedependent reduction. The concentration of free malondialdehyde (MDA) was determined by reaction with 1-methyl-2-phenylindole [3].

Statistical processing of the study results was carried out using the Microsoft Office Excel software and the Real Statistics 2019 extension to it. The nonparametric Mann-Whitney test was used to determine the statistical significance of differences between the groups. The difference was considered statistically significant at $p<0.05$.

\section{Results and discussion}

Studying semi-thin sections of the liver of the experimental group of animals on the 270th day of the experiment, we found that the reaction to the central blockage of luteinizing hormone in the structure of the organ is determined by changes in both the stromal and parenchymal components. The liver architectonics is preserved. When studying the anastomosing plates of hepatocytes, it was found that the connective tissue spaces are significantly thickened and compacted due to the growth of collagen in comparison with the control group of animals. The bile ducts were dilated, the walls were compacted. They were characterized by stale bile.

On the vascular side, stasis was observed. The central veins were dilated, full-blooded, erythrocytes and a large number of leukocytes were determined in their lumen as compared to the control group of animals. The venous stasis was also observed in the vessels of the hepatic triads. Sinusoidal capillaries for the most part are dilated, full-blooded. An increase of their diameter is preserved throughout from the triad to the central vein, due to an increase of the inner diameter (Fig. 1).

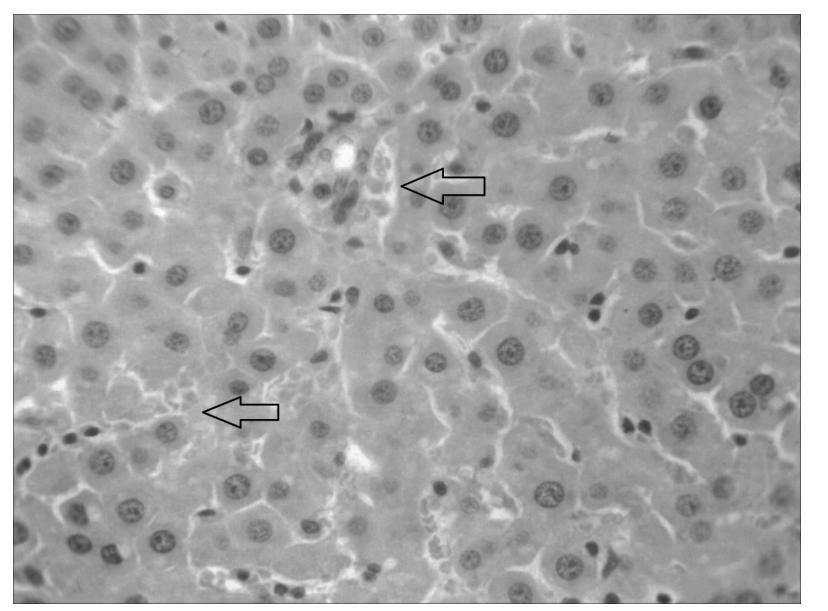

Fig. 1. Stasis in the blood vessels of the rat liver hemomicrocirculatory bed on the 270th day of the experiment. Hematoxylin and eosin stain.

Magnification: Lens x 40, Eyepiece x 10 .

When we studied the parenchymal component of the liver, namely hepatocytes, the cells were divided into several groups depending on the state of the nuclei and cytoplasm. Hence, according to the color of the cytoplasm, we distinguished two groups: basophilic and oxyphilic stained cells. According to the state of the nuclei, the cells were divided into mononucleated and binucleated; by the number of nucleoli, respectively, into oneand two-nucleolar hepatocytes (Fig. 2, 3). 


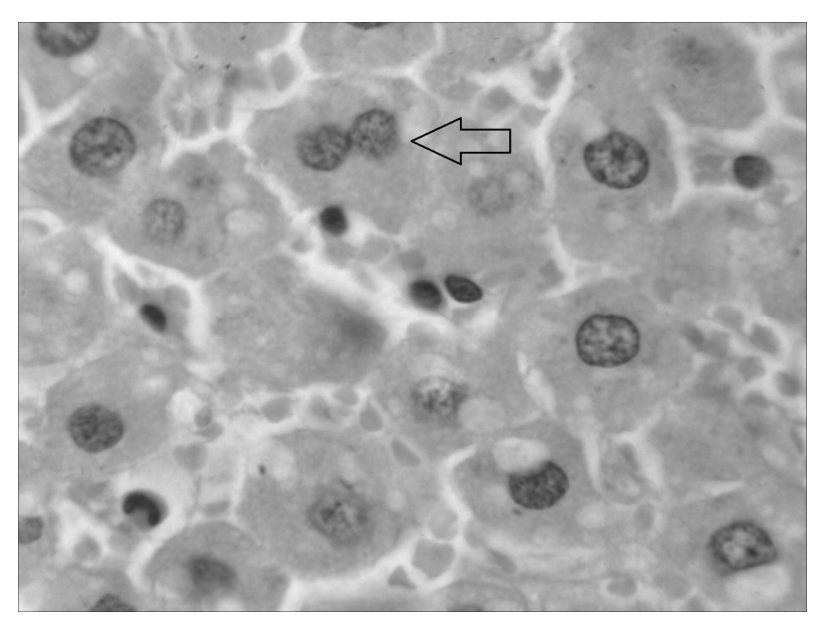

Fig. 2. Binucleated rat liver cells on the 270th day of the experiment. Hematoxylin and eosin stain. Magnification Lens $\times 100$, Eyepiece $\times 10$.

Most of the hepatocytes differed in structural characteristics on semi-thin sections. Most of the cells were with nuclei at the stage of karyopyknosis, with different densities of the nucleus. The volume of the nucleus was $1602.09 \pm 44.58 \mu^{3}$, which is by 2 times lower $(p<0.001)$ as compared to the control group of animals. The number of binucleated hepatocytes decreased noticeably, the cytoplasm of most cells had oxyphilic granularity. Most of the hepatocytes had an enlarged volume of cytoplasm $28646.49 \pm 1344.28 \mu^{3}$, which is by 3 times higher $(p<0.001)$ as compared to the control group of animals. The spatial localization of oxyphilic hepatocytes was determined closer to the central vein. Basophilic hepatocytes were found on the periphery of the hepatic lobule.

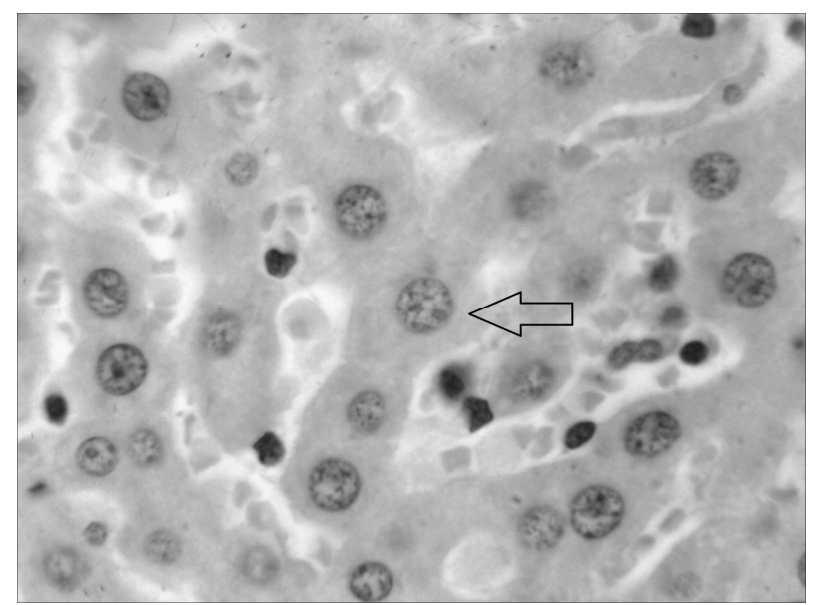

Fig. 3. Two-nucleolar hepatocytes of rat liver on the 270th day of the experiment. Hematoxylin and eosin stain. Magnification: Lens $x$ 100, Eyepiece x 10 .
The 360th day of the experiment was characterized by the fact that the destruction of the stroma and parenchyma was not observed. The structure of plates of hepatocytes is retained. Hepatic plates are enlarged, thickened, edematous. The bile ducts are dilated. The vessels of the hepatic triads are full-blooded, the walls are greater density. The central veins are slightly dilated and plethoric as compared to the control group of animals, but noticeably less as compared to the previous period. The capillaries are slightly dilated and slightly plethoric (Fig. 4).

It was found that most hepatocytes have nuclei with clear karyopyknotic changes. The average size of the nuclei volume was $1955.69 \pm 61.35 \mu \mathrm{m}^{3}$, which is by 1.7 times lower $(p<0.001)$ than in the control group. The volume of hepatocytes cytoplasm was $25841.64 \pm 1123.68$ $\mu \mathrm{m}^{3}$, which is by 3 times higher $(p<0.001)$ than in the control group. Their cytoplasm is eosinophilic with areas of vacuolization (Fig. 4).

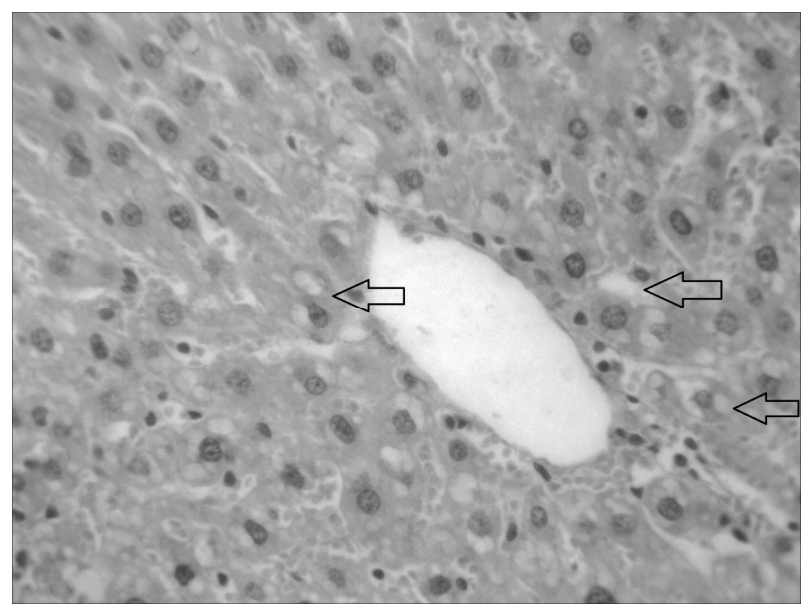

Fig. 4. Modified hepatocytes on the 360th day of the experiment. Hematoxylin and eosin stain. Magnification:

$$
\text { Lens } x \text { 40, Eyepiece } \times 10 \text {. }
$$

Central deprivation of the synthesis of luteinizing hormone by triptorelin on day 270 led to an increase in the production of superoxide anion radical by 1.53 times as compared to the control group of animals (table. 1). SOD activity decreases by 2.08 times, and catalase activity - by 1.51 times as compared to the control group of animals. The concentration of free malonic dialdehyde increase by 1.51 times.

On the 360th day of central deprivation of the synthesis of luteinizing hormone by triptorelin, the production of superoxide anion-radical increased by 1.31 times as compared to the control group and decreased by $14.81 \%$ as compared to 270 days of the experiment.

Table 1.

Changes of oxidative stress biomarkers in rat liver during prolonged central deprivation of testosterone synthesis $(M \pm m)$.

\begin{tabular}{|c|c|c|c|}
\hline Parameters & Control group & 270 days & 360 days \\
\hline $\begin{array}{c}\text { Production of SAR, } \\
\text { nmol/s on g of tissue }\end{array}$ & $1.76 \pm 0.05$ & $2.70 \pm 0.01^{*}$ & $2.30 \pm 0.02^{\star / * *}$ \\
\hline Activity of SOD, c.u. & $10.12 \pm 1.54$ & $4.87 \pm 0.27^{*}$ & $6.37 \pm 0.50^{\star / * *}$ \\
\hline $\begin{array}{c}\text { Activity of catalase } \\
\mu \mathrm{kat} / \mathrm{g} \text { of tissue }\end{array}$ & $0.379 \pm 0.001$ & $0.251 \pm 0.002^{*}$ & $18.31 \pm 0.08^{* /{ }^{* *}}$ \\
\hline $\begin{array}{c}\text { Concentration of free } \\
\mathrm{MDA}, \mu \mathrm{mol} / \mathrm{g} \text { of tissue }\end{array}$ & $14.04 \pm 0.20$ & $21.16 \pm 0.08^{*}$ & $1.002^{\star / *}$ \\
\hline
\end{tabular}

Note: * * indicates that data is statistically significantly different as compared to the control group $(p<0.05) 4$

** - indicates that data is statistically significantly different as compared to the previous period of the experiment $(p<0.05)$. 
The activity of superoxide dismutase decreases by 1.59 times as compared to the control group of animals and increases by 1.31 times as compared to the 270th day of the experiment. The activity of catalase decreases by 1.43 times as compared to the control group and increases by $5.56 \%$ as compared to the 270 th day of the experiment.

The concentration of free MDA increases by 1.3 times as compared to the control group and decreases by $13.47 \%$ as compared to the 270 th day.

Thus, on days 270 and 360 of central deprivation of luteinizing hormone synthesis by triptorelin, the development of oxidative damage to hepatocytes is observed. However, on day 360 , the intensity of oxidative stress is lower than on day 270 , which is due to an increase in the activity of antioxidant enzymes and a decrease in the production of reactive oxygen species.

The development of oxidative stress in the liver tissues may be associated with a decrease in testosterone concentration under the influence of triptorelin. Testosterone has the property of decreasing the number of macrophages polarized by the pro-inflammatory phenotype (M1) and increasing the number of macrophages polarized by the anti-inflammatory phenotype (M2) $[10,11]$. Thus, a decrease in testosterone concentration can lead to an increase in the production of reactive oxygen species by liver macrophages. Testosterone is also able to reduce the production of reactive oxygen species by mitochondria [4]. Testosterone deficiency can lead to increased production of superoxide radical anion in liver mitochondria.

Therefore, an increase in the production of superoxide radical anion in rat liver may be due to the absence of an inhibitory effect of testosterone on macrophages and liver mitochondria, which is accompanied by depletion of antioxidant enzymes and the development of oxidative stress.

\section{Conclusion}

1. With longer central deprivation of the luteinizing hormone synthesis by triptorelin, the development of oxidative damage to the stromal component of the liver was observed. It was characterized by stasis in the vessels of the microcirculatory bed with maximum values on the 270th day of the experiment.

2. The reaction of the liver parenchyma was manifested by an increase in the number of hepatocytes with karyopyknosis and oxyphilic cytoplasm with a large number of vacuoles, with localization closer to the central vein.

3. The intensity of biochemical markers of oxidative stress on the 360th day is lower than on the 270th day, which is due to an increase in the activity of antioxi- dant enzymes and a decrease in the production of reactive oxygen species.

\section{References}

1. Bahriy MM, Dibrova VA, Popadynets $\mathrm{OH}$, Hryshchuk MI. Metodyky morfolohichnykh doslidzhen. Bahriy MM, Dibrova VA. redaktory. Vinnytsya: Nova knyha; 2016. 328s. [in Ukrainian]

2. Bell MA, Campbell JD, Joice G, Sopko NA, Burnett AL. Shifting the Paradigm of Testosterone Replacement Therapy in Prostate Cancer. World J Mens Health. 2018 May;36(2):103-109. doi: 10.5534/wjmh.170007.

4. Gur S, Alzweri L, Yilmaz-Oral D, Kaya-Sezginer E, AbdelMageed AB, Dick B, Sikka SC, Volkan Oztekin C, Hellstrom WJG. Testosterone positively regulates functional responses and nitric oxide expression in the isolated human corpus cavernosum. Andrology. 2020 Nov; 8(6):18241833. doi: $10.1111 / a n d r .12866$.

5. Kang J, Jia Z, Ping Y, Liu Z, Yan X, Xing G, Yan W. Testosterone alleviates mitochondrial ROS accumulation and mitochondria-mediated apoptosis in the gastric mucosa of orchiectomized rats. Arch Biochem Biophys. 2018 Jul 1;649:53-59. doi: 10.1016/j.abb.2018.05.002.

6. Komura K, Sweeney CJ, Inamoto T, Ibuki N, Azuma H, Kantoff PW. Current treatment strategies for advanced prostate cancer. Int J Urol. 2018 Mar;25(3):220-231. doi: 10.1111/iju.13512.

7. Merseburger AS, Hupe MC. An Update on Triptorelin: Current Thinking on Androgen Deprivation Therapy for Prostate Cancer. Adv Ther. 2016 Jul;33(7):1072-93. doi: 10.1007/s12325-016-0351-4.

8. Polyvyana O.A., Shepitko K.V., Stetsuk Ye.V., Akimov O.Ye., Dubinin D.S.. Influence of prolonged tripterelininduced central deprivation of testosterone synthesis on morphological structure of rat's liver. World of medicine and biology. 2021; 1(75): 205-209. DOI 10.26724/20798334-2021-1-75-205-209

9. Shim M, Bang WJ, Oh CY, Lee YS, Cho JS. Effectiveness of three different luteinizing hormone-releasing hormone agonists in the chemical castration of patients with prostate cancer: Goserelin versus triptorelin versus leuprolide. Investig Clin Urol. 2019 Jul;60(4):244-250. doi: 10.4111/icu.2019.60.4.244.

10. Son BK, Kojima T, Ogawa S, Akishita M. Testosterone inhibits aneurysm formation and vascular inflammation in male mice. J Endocrinol. 2019 Jun 1;241(3):307-317. doi: 10.1530/JOE-18-0646.

11. Son SW, Lee JS, Kim HG, Kim DW, Ahn YC, Son CG. Testosterone depletion increases the susceptibility of brain tissue to oxidative damage in a restraint stress mouse model. J Neurochem. 2016 Jan;136(1):106-17. doi: 10.1111/jnc. 13371.

12. Stetsuk YeV, Akimov OYe, Shepitko KV, Goltsev AN. Structural organization of stromal and parenchymal components of rat testes during central deprivation of testosterone synthesis on the 180 day of the experiment. World of medicine and biology. 2020; 72(2): 203-207. Doi: 10.26724/2079-8334-2020-2-72-203-207.

Матеріал надійшов до редакції 01.11.2021. 